\title{
The intersection of professionalism gay men, bodies and power
}

Simon Peter Roberts

\section{Introduction}

The aim of this paper is to explore how gay men manage their social identities in the workplace. It explores how gay men use their bodies in the workplace in their role as professionals in positions which demand them to exercise authority. Previous academics have noted the link between professionalism and heteronormative masculinity (Connell, 1995; Bruni and Gherardi, 2001; Whitehead, 2002; Rumens and Kerfoot, 2009). The paper highlights how professionalism can serve as a form of exclusion for those who do not adhere to what are perceived as normative forms of masculinity.

The body as Shilling (1993) argues is at the core of a person's sense of self-identity. Indeed, as Jenkins (2008/2014) points out, selves and our identities do not make much sense without bodies. Bodies are important as they project how others perceive and evaluate us in our interactions. Furthermore, as Shilling (1993) states the social meanings that are linked to the bodily forms and performance have a significant impact upon how we see ourselves and our inner worth. Bodies and bodily behaviour is one of the ways in which we evaluate others. Previous studies have highlighted the absence of empirical research on the centrality of bodies to how we shape our identities (Whitehead, 2002; Gill et al., 2005; Fassinger et al., 2010 and Mclvor, 2014). Added to which, Drummond (2004, p. 272) argues that there has been a paucity of qualitative research on the subject of gay men's bodies. Furthermore, as briefly touched upon in Rumens and Kerfoot's (2009) study on gay male professionals, there is a limited amount known about how gay men construct their identities using their bodies. The aim of this paper is to shed some light in this under researched area.

\section{Theoretical framework}

Closely linked to the regulation of bodies in the workplace in relation to this paper is the theoretical discussion around a particular form of masculinity associated with management. Collinson and Hearn (1994), for example, argue that "being a man" and "being a manager" are synonymous. In fact, they rephrase the term management to man-agement. A number of theorists (Whitehead, 2002; Collinson and Hearn, 1994; Young, 1990) have attempted to define the attributes of what a successful manager is expected to have. Included in the list of attributes are: ruthlessness, controlling, lack of emotion, aggressiveness, abrasiveness and an autocratic style of management all perceived as masculine attributes. According to Collinson and Hearn (1994) the most important attribute, however, is the possession of personal power and the ability to control others and the self. The assumption here is that a lack of these attributes would draw questions around an individual's effectiveness as a manager.

At the core of this paper's conceptual framework is Jenkins' (2008/2014) concept of the interaction order from his theoretical study of social identity. Jenkins $(2008 / 2014)$ defines the interaction order as where our self-identities (internal) meet with the external moment or as the dilemma surrounding the internal-external dialectic. The internal moment of the dialectic of identification (defined as the image individuals present of themselves for acceptance by others) meets with the 
external moment (defined as the reception and response of others of that presentation). According to Jenkins, identities are not unilaterally constructed. Identity construction is a two-way process. For individuals, asserting an identity is not sufficient as identity construction is also dependent on categorisation by others and meanings others we interact with place on such identities. In many respects, how we see ourselves may be very different to how others see us. Just as each of us identifies others, equally others identify us in turn. Consequently, what people think about us is no less significant than what we think about ourselves. It is dialectical due to the fact that the two aspects of identity are contesting and negotiating over the different meanings placed on identities. The dilemma faced with the interaction order is that we cannot fully manage or control the outcomes of the presentation of ourselves and our bodies we project to others. Even though people have some control over the signals about themselves that they send to others, we are all at a disadvantage in that we cannot ensure either their "correct" reception or interpretation or know with certainty how they are received or interpreted. (Jenkins, 2008/2014, p. 42). Consequently, it is not enough to assert an identity that assertion must also be validated, or not, by those with whom we have dealings. The Figure 1 is an adaption of Jenkins' analytical framework in relation to how gay men present their bodies and themselves and manage their gay identity in the workplace.

\section{Figure 1}

A core concept that shapes how gay men present their professional selves through their bodies is heteronormativity. Ingraham (2006, p. 309), who first coined the term heteronormativity, defines it as "the belief system underlying institutionalised heterosexuality [that] constitutes the dominant Western paradigm in Western society". Heteronormativity is a regulatory practice that constrains and limits the expression of nonheterosexual forms of expression. Unlike homophobia, it usually functions in a much subtler manner, manifested through societal expectations, peer pressure and as a norm of behaviour. Heteronormativity draws attention to the privileged status of heterosexuality in organisational settings.

Previous studies pertaining to professional gay men, bodies and performance in the workplace have predominately focused on what Miller et al. (2003) and Rumens and Broomfield (2012) refer to as hyper-masculine occupations such as the Police and the Fire Service (Miller et al., 2003; Burke, 1993; Rumens and Broomfield, 2012; Ward, 2008). These studies have shown how gay men have felt constrained in having to sacrifice parts of their gay identity in order to fit into the behaviour and conduct expected of a professional. There have however been few studies exploring how gay men regulate and manage their bodies beyond these hyper-masculine occupations. In fact, there has been little discussion or empirical investigation on the experiences of gay men in positions of authority and the dilemmas they may face.

Nevertheless, there have been a few empirical studies where perceived masculine attributes have regulated the ways that both men and women have presented their bodies in the workplace (Hall et al., 2007; Fassinger et al., 2010; McDowell and Court, 1994). McDowell and Court (1994) in their pioneering study of women and their bodies noted how women would try to fit into the existing norms of behaviour in the City of London financial institutions by inscribing their bodies as masculine. Similar findings were uncovered in Hall et al.'s study (2007) where body management was not solely restricted to women but also men. Fassinger et al. (2010) built upon these studies by looking beyond solely the issue of gender in management. They also investigated the impact of 
presenting an openly gay identity in leadership positions within the teaching profession. Similar to studies on women they noted how openly gay male leaders had to prove their masculinity. They concluded that for an out gay male teacher to be perceived as effective they had to conform to expected gender norms and not to "flaunt" their homosexuality.

In these studies outlined above there would seem to be a degree of internal reflection, where individuals reflexively construct and reconstruct how they project their bodies in order to fit in. Giddens (1991) refers to this as constructing "body projects". Previous studies have shown that gay men are particularly conscious and reflective in how they present their bodies and in what they wear (Frankham, 2001; Drummond, 2004).

A theme running throughout this paper is the issue of agency vs constraint. As Shilling (1993) argues the body can be both enabling and constraining at the same time. As Bradley (2007) in her theoretical study on gender points out our identities as gendered beings are not imposed upon us. In other words, we do not passively wait for our identities to be shaped and moulded by the processes that surround us. Rumens and Kerfoot (2009) noted in their study of gay male professionals that there appeared to be some degree of empowerment, but nevertheless, equally they were constrained by the dominant professional norms and discourses of heteronormativity. Similarly, Whitehead (2002) argues that individuals do have a degree of choice in their gendered embodiment. This does however entail struggle and resistance. Hence, body projects are negotiated and contested terrains in what Jenkins (2008/2014) would refer to as the interaction order.

\section{Methods}

The study data were collected as part of a wider research project exploring how gay men manage their identity in the workplace. The study was conducted in the UK between 2010 and 2012. In this paper, data were drawn from eight gay men working in a town on the South coast of England. In line with most research on the LGBT population (Martin and Dean, 1993; Cooper, 2006; Platzer and James, 1997; Homfray, 2008; Rumens, 2008), self-identification or self-definition was used as the primary criterion for participation. The degree of openness about disclosure of their sexuality varied. Two of the participants listed below $(*)$ chose not to reveal their sexual orientation in the workplace. Participants ranged in age from 29 to 63 . All of the participants were in occupations that required them to exercise authority over others in the workplace. This exercise of authority included: dealing with unruly kids in the classroom, managing subordinates and disciplining behaviour, dealing with potential criminals in the street and assessing health and safety standards in food serving premises. In order to preserve anonymity and to ensure ethical issues were adhered to, all participants were given pseudonyms. Demographic characteristics of study participants and a brief description of the organisational environment they described are outlined in Table I.

The study adopted a qualitative and inductive methodological approach. In line with previous research on sexual minorities (Burke, 1993; Ward, 2008; Shallenberger, 1994), semi-structured interviews were deployed. Interviews lasted between $50 \mathrm{~min}$ and one and a half hours. This approach generated rich in-depth responses from participants from which the study findings emerged. The data were analysed thematically after coding the data using Nvivo analytical software.

\section{Empirical findings}


Control and the exercise of authority

Research data revealed that many participants felt they had to regulate and control the way they presented their body especially where they had to exercise authority over others. All of the respondents were in occupations that required them to exert their authority over others in order to be perceived as effective in their role. The general sentiment was that participants had to be vigilant in the ways they portrayed their bodies in the workplace. This was particularly the case for Dean, even though he took on the role of a lesbian and gay liaison police officer to champion their rights, he felt compromised when out on the beat. Dean believed that he needed to be more guarded in how he presented himself to the general public:

I think for me the biggest worry would be members of the public picking up on my sexuality [...] I think I'm more guarded. Yeah, I'm out. I'm a police officer first and that's my role and that's my uniform. I have to be that professional image. I don't want to give anything to anyone that they could use to get an advantage over me. You have to be able to know that I can control the situation and if needs be control the person and perhaps arrest them.

\section{Table}

At the police station amongst his work colleagues Dean is open about his sexuality and actively promotes gay and lesbian equality. However, when he has to be out on the public stage, he feels he has to conceal his sexuality through his uniform and his role as a police officer. In the above quote, Dean uses the words "control" and "get an advantage over". The key theme here is the issue of power and authority. He feels that his authority would be undermined or questioned if his gay identity became visible. Of course, authoritative power is a relative construct. As French and Raven (1968) argue, like referent power, it is dependent on subordinates believing that the individual has a right to exercise power because of their role. Furthermore, the power is only effective if subordinates identify with the performance of the police officer. Consequently, Dean feels that his powers as an effective police officer would be diminished in the eyes of the general public, if he showed visible signs of his sexuality in how he presented his body on the beat. In his interaction with others on the beat he adapts his presentation of self-adopting normative heterosexual masculine behaviours in how his body is exercised. One of the issues in adopting a "normalising" approach as Rumens and Tyler (2016) state is that gay men have to present their similarities with normative constructions of male heterosexuality. We also see how Dean feels he has to be "guarded" in how he presents himself in pubic as a policeman. Underpinning this are the normative pressures that Dean experiences. In a desire to be taken seriously as a professional, he adapts his presentation to what are perceived to be normative cultural understandings of what it means to be a policeman.

The construction of becoming "openly gay" is one which is mediated by sexual and gender norms displayed in organisational discourses of heteronormativity. Godfrey's experience as an environmental health inspector draws parallels with Dean's story as a police officer. Godfrey's performance of his sexuality in the workplace was mediated by heteronormativity. Like Dean, amongst his work colleagues within the workplace he felt he could be less guarded in how he presented himself. He would use camp humour and send himself up in the office. This contrasted with how he presented himself whilst inspecting food hygiene in restaurants and hotels: 
I do [a job] where you might have to confront people [...] I'm in a job, which is butch, if you like, or it's not an arty [job]. I'm in a job where you're confronting people potentially and I don't want to be mincing all day long and waving my knickers in the air, where I'm going to a food establishment, possibly with a colleague, trying to put on a deep voice and being all manly and all that [...] [...], if there is a problem is with me, because it's difficult having a sort of schizophrenic life, where you're being assertive, not aggressive but you're being assertive and you've got to assert the legal position.

Here Godfrey feels required to conform to normative forms of heterosexual masculinity in how he uses his body whilst inspecting food premises. Godfrey consciously deepens his voice and behaves in what he terms an "all manly" manner. The story illustrates the dilemmas in how Godfrey presents his professional self at work. In what he terms a "schizophrenic life" in his interactions with others he feels he has to modify his behaviour depending on whether it is his work colleagues or members of the public.

The impact of organisational heteronormativity was also depicted in those participants who worked in the teaching profession. Organisational heteronormativity regulated not only how they managed their bodies but also how they should dress. Nigel, for example, a secondary school teacher, would always wear a dark suit, tie and white shirt to work to present what he deemed as a professional image fitting for the role of a teacher. All three teachers in the sample would regulate how they behaved and presented their bodies in the classroom in order to maintain control over their pupils. There was a heightened awareness of how they presented themselves, monitoring their behaviour in front of others. Stan, a deputy head of a primary school, for example, was guarded in how he used his body. In particular, he was concerned how others might evaluate him. He would therefore modify how he presented himself in his interactions with others in the workplace:

I think in a school setting you have this other level where people are looking very closely at you [...].So I am very conscious of how they might be reading me. [...] [...] when I go for interview that's a good example. I would be very conscious about the way I sat or the way I spoke, the way I shook somebody's hand [...] especially in the position that I was taking on that people were looking at me and making judgements about me, the parents especially [...] and because of the position of authority I've had to speak to quite a lot of parents and difficult situations, so just conscious of being looked at and watched.

Interestingly, Stan believes that because he holds a position of authority that places extra pressure on him and on how he presents himself. Likewise, Pablo, also a primary school teacher, believed he needed to "butch it up" in order to earn the respect of the pupils. Collinson and Hearn (1994) identify five forms of masculinity pervasive in managerial discourses and practices. They associate authoritarianism with a particular form of masculinity based on aggressiveness. They theoretically argue that those who use authoritarianism do so to heighten their masculinity. It could therefore be the case that gay men might feel that in their interactions with others, they have to enact this form of masculinity in order to validate their identities and to be accepted by others. There is limited scope in behaving in non-normative forms of heterosexual masculinity in the school grounds. What is evident here is that when a teacher speaks, looks, behaves or presents as what might be perceived as gay this would seem to be incongruous to the expected ideals of the teaching profession. Although Section 28 of the Local Government Act (1988) had been repealed in 2003, the Act still seemed to have some hold over the teachers in how they behaved in the classroom. In fact, 
respondents admitted that Section 28 still overshadowed how they managed their gay identity in the classroom. As Nigel expressed:

I do believe as a teacher you do, something that goes with the salary, is the fact that you've got to actually monitor your own behaviour. It's one of the few professions left where you have got to be morally superior to everyone [...]. Each [job] move I've definitely played it [my sexuality] down more.

Nigel discursively constructs a gay male subject position that requires him to monitor his behaviour to the extent that he believes he has to be "morally superior". Here Nigel invokes notions of respectability and in effect an allegiance to heteronormative values. "Morally superior" would seem to suggest one that upholds heteronormative moral values, where alternative sexualities are regulated and cleaned up in order to meet these standards. The dilemma these teachers face is how they construct themselves as role models within their schools in front of pupils and parents whilst at the same time preserve how they would like to present their gay identity.

A common theme running through these stories is an attempt to normalise a gay identity. The assumption being that normalisation would mean they would fit in better in their respective organisations. It would appear that participants were assimilating their behaviours and how they used their bodies using heteronormative masculinity as the standard to emulate. This is depicted in how Ivan perceives his effectiveness as an openly gay manager of a glass making factory:

I am kind of senior management in charge of my own side of things, it's kind of easier to deal with [his sexuality] and I am not easily offended I suppose. I am I suppose quite straight acting as well. I suppose effeminate guys could find it a bit more difficult.

Here Ivan uses the term "straight acting" in how he believes he presents himself as a manager to his subordinates. The phrase "straight acting" would seem to suggest that he presents himself in heteronormative masculine terms. Ivan feels that by adopting normative masculine behaviours it would make his position as a manager less challenging. This would seem to support the theoretical argument (Collinson and Hearn, 1994; Whitehead, 2002; Young, 1990) that management is very much a masculine domain. In order to be an effective holder of the position, a manager needs to be ruthless, controlling and aggressive in their behaviour. Consequently, by adopting more normative masculine attributes, Ivan believes he is able to assert control over his subordinates more effectively.

The research data also revealed how normative discourses of professionalism shaped how participants behaved in the workplace. As with previous studies (Rumens and Kerfoot, 2009), they were wary of what clothes they wore or how they presented their bodies in their organisations. The prevailing theme was an attempt to mask or downplay their sexuality in order not to look incongruent with the normative ideals of professionalism. As discussed above, Nigel would wear sober dark suits and white shirts to emit a professional image. Pat, a lawyer who had reached partnership status described his workplace as being "macho" where social events with clients were based around sporting activities. The culture of his organisation was one in which he felt he had to conform by "fitting in" in order to be successful. Pat, who was not out at work, would be vigilant in the ways he used his body and the clothes he wore for fear it might disclose his gay identity: 
I would try and keep my voice down or dress conservatively. I have a pink tie, for example, and when I wear it I'm conscious that it's somehow shouting that I'm gay or whatever, but I do wear it, but not that frequently.

Of course, the colour pink still has socially constructed meanings associated with femininity in western cultures. Normative discourses around professional attire pertain that professionalism requires the wearing of sober, conservative clothes so as not to draw attention to any difference. By choosing not to wear pink, Pat attempts to fit in to what are deemed gender appropriate attire. Pat revealed the stress he has suffered in order to assimilate into the organisational norms in how he manages his body and the clothes he wears in the workplace:

But stress for me is not kind of fitting into the norm to the mould of being a macho man really. It isn't covering it up. It's just that I'd like to fit into it [the organisation] really because I think if I did I would be more successful.

Pat conforms to the pressures of hegemonic heterosexual masculinity in order to not only be accepted by his work colleagues but also to be seen as a successful lawyer. Pat story highlights the lack of inclusiveness he experienced within his organisation.

Clothes were used by participants as a cloak of professionalism. Certainly, uniforms and their accoutrement aided in giving them a sense of control and authority in the workplace. This was noted in Reg's account as a project surveyor on building sites:

They don't know who I am or what I am. They just take me. I am the project. I am the contract administrator or the person who is running the job. I've got the badge on. I've got the hat on. It's a professional person and that's the persona I like to have at work. I try and keep totally professional in my job [...] I think I am looked on as a professional person. At work I'm treated totally as a professional. I am respected as a professional person and that's how I want it. I am who I am, you know. I'm running that project and it has taken me years to get to that point and I jealously guard that position. So I don't want it undermined by them having a reason to think that I was a poof, you know.

It would seem that any visible sign of his gay identity would be incongruous with the normative ideals of professionalism. Reg attempts to shape and construct how he presents himself around what he deems as being professional. He uses the props of his protective helmet and his badge which identifies him as a project surveyor to give him control and the respect of others. Reg fears that others might label him as a "poof". Here, Reg expresses internalised homophobia.

\section{Camp - a challenge to heteronormativity?}

As discussed earlier in this paper, the extant literature reveals that gay men have a degree of empowerment and agency in their gendered embodiment and how they wish to present themselves in the workplace (Shilling, 1993; Bradley, 2007; Rumens and Kerfoot, 2009). The study data uncovered times when participants would disrupt gender binaries and act in ways that would be considered as going against normative forms of masculinity. A few of the participants would deliberately "camp it up" in their self-presentation in order to entertain. Nigel, a secondary school teacher, recalls the dilemmas around how he performs his role in the classroom: 
I am quite camp when I teach actually. I'm quite a flamboyant teacher. I would describe it as a performance. I do feel when you're teaching that to maintain a level of interest, you've got to have variations in the way you speak within my classroom. I'm a performer. [...] [...] depending on the situation. However, there are situations where a very stern disciplinary approach is needed and at which point I would describe myself as straightening up a bit [...]. but it's not a professional image.

Nigel believes that in order to get the pupils engaged and interested in his lessons he needs to put on a performance. He would deliberately be flamboyant and alter the pitch of his voice to amuse the children. Of course, camp performances are an entrenched part of British culture as portrayed in popular TV comedies and plays. Camp performances are seen as entertaining as they parody and go against socially constructed gendered behaviour. Nigel illustrates what Butler (1990) would refer to as the performativity of gender. Nigel disrupts normative masculinity in his performances in the classroom. Nigel seems to gain pleasure in the opportunity to express his sexuality that has the potential to contest heteronormative expectations of a teacher. Camp is a vehicle to establish a connection with the pupils to get them enthused in his lesson. Camp also has the potential to denaturalise and challenge heteronormative constructions of sexual identities. Nevertheless, camp performances can backfire. Rather than disrupting heteronormativity it can do the opposite and reinforce heteronormative values. In fact, Nigel noted how his pupils would on occasion mock his performances by mimicking him behind his back. As Connell (2015) noted in her study of gay and lesbian teachers in USA, camp behaviour was perceived as a distraction and an impediment to effective teaching in the classroom. Interestingly, in the above quote, what we see is that different work contexts impact on the type of performance enacted. During his teaching, Nigel feels he can "camp it up". This contrasts with where he has to discipline a pupil for unruly behaviour. On these occasions, Nigel believes he has to "straighten up" in order to be perceived by others as a professional. In what Jenkins (2008/2014) would refer to as the interaction order, Nigel conforms to heteronormative expectations of how a professional is expected to act. In a desire to be taken seriously as an openly gay professional Nigel conforms to normative expectations of what it means to be a professional. Nigel's story illustrates the lack of inclusivity that professions such as teaching provide in encouraging alternative ways of presenting a professional identity in the classroom. We can see how Nigel manages his performance as a secondary school teacher mediated by organisational heteronormativity. There is limited scope in how he identifies and performs as a teacher with authority. There is a fine dividing line between an acceptable presentation of self in the classroom as a professional and standing out and facing possible ridicule.

\section{Conclusion and discussion}

This paper adds to our understanding of how gay men in positions of authority feel they need to conform in order to fit in within the expected heteronormative expectations attached to these roles. The findings predominately illustrate stories where professionalism reinforces specific gender conventional displays of masculinity amongst the participants. This paper brings to the fore wider implications of inclusiveness in the workplace and what it means to be a professional. As feminist writers (Webb, 1997; Bacchi, 1990; Liff and Wajcman, 1996; Young, 1990) have previously pointed out, employing an assimilation approach of "fitting in" requires others to deny or minimise their differences. This also draws parallel implications for gay men, where they are expected to model themselves on heterosexual men and their attributes, playing down their differences in how they present their professional selves. This paper builds upon previous feminist writers (Bell and Nkomo, 
2003; Bruni and Gherardi, 2001; Whitehead, 2002) bringing into question the understanding of what it means to be a professional. This paper has wider implications for organisations. As previous studies (Kandola and Fullerton, 1998; Colgan and Rumens, 2015) have argued, organisations that strive for inclusiveness and embrace difference can expect to see improvements in organisational performance and effectiveness.

This paper adds to a dearth of studies on gay men, professionalism and managing their bodies, selves and identities in the workplace. The paper builds upon and contributes to our understanding of how gay men use and construct their bodies and their self-identities as professionals. An area that has had little empirical investigation. Furthermore, the paper contributes to our understanding of organisational heteronormativity and professionalism in the workplace. The richness of the empirical data sheds light on how heteronormativity regulates the ways in which gay men present their professional selves at work. In addition, the paper contributes to our existing knowledge about how professional gay men adopt alternative approaches in how they choose to present themselves as professionals. Predominately, the stories illustrated in this paper are of individuals adopting normalising strategies in how they present their professional selves. This was particularly the case where respondents had to exercise authority. The stories illustrated how normative constructions of identity were organised around heterosexuality. Normalising required participants to build identities that shared many of the qualities of their heterosexual counterparts.

In the model presented above (Figure 1), as Jenkins argues, social identities are a two-way process of both internal and external dimensions. This paper has brought into focus how professional gay identities are marked by negotiation and struggle in what Jenkins refers to as the interaction order. Of course, we can never be certain what identities are ascribed by others. This paper did not interview others to explore what meanings they attach to the term professionalism. Further research needs to investigate what people's understanding are of the term professionalism and what it means today. Investigations are needed to explore whether professionalism is still perceived in terms associated with heteronormative masculinity (Collinson and Hearn, 1994; Connell, 1995; Whitehead, 2002).

\section{References}

Bacchi, C. (1990), Same Difference: Feminism and Sexual Difference, Allen \& Unwin, Sydney.

Bell, E.L.J. and Nkomo, S.M. (2003), Our Separate Ways: Black and White Women and The Struggles for Professional Identity, Harvard Business Press, Boston, MA.

Bradley, H. (2007), Gender, Polity Press, Cambridge. Bruni, A. and Gherardi, S. (2001), “Omega's story: the heterogeneous engineering of a gendered professional self", in Dent, M. and Whitehead, S. (Eds), Managing Professional Identities, Knowledge, Performativity and the "New" Professional, Routledge, London, pp. 174-198.

Burke, M. (1993), Coming Out of the Blue, Cassell, London.

Butler, J. (1990), Gender Trouble, Routledge, Abingdon.

Colgan, F. and Rumens, N. (2015), Sexual Orientation at Work. Contemporary issues and Perspectives, Routledge, London. 
Collinson, D. and Hearn, J. (1994), "Naming men as men: implications for work, organization and management", Gender, Work and Organization, Vol. 1 No. 1, pp. 2-22.

Connell, C. (2015), School's Out: Gay and Lesbian Teachers in the Classroom, University of California, Oakland, CA.

Connell, R.W. (1995), Masculinities, Polity Press, Cambridge.

Cooper, A. (2006), "Identity work: negotiating gay male identities in a changing world", PhD thesis, London South Bank University, London.

Drummond, M. (2004), “Men's bodies: listening to the voices of young gay men”, Men and Masculinities, Vol. 7 No. 3, pp. 270-290.

Fassinger, R., Shullman, S. and Stevenson, M. (2010), "Toward an afformative lesbian, gay, bisexual, and transgender leadership paradigm", American Psychologist, Vol. 65 No. 3, pp. 201-215.

Frankham, J. (2001), "The 'open secret': limitations on the expression of same sex desire", Qualitative Studies in Education, Vol. 14 No. 4, pp. 457-469.

French, J. and Raven, B. (1968), "The basis of social power", in Cartwright, D. and Zander, A. (Eds), Group Dynamics: Research and Theory, 3rd ed., Harper \& Row, New York, NY, pp. 259-269.

Giddens, A. (1991), Modernity and Self-Identity, Polity Press, Cambridge.

Gill, R., Henwood, K. and McLean, C. (2005), "Body projects and the regulation of normative masculinity", Body and Society, Vol. 11 No. 37, pp. 37-62.

Hall, A., Hockley, J. and Robinson, V. (2007), "Occupational cultures and the embodiment of masculinity: hairdressing, estate agency and firefighting", Gender, Work and Society, Vol. 14 No. 6, pp. 534-551.

Homfray, M. (2008), "Standpoint, objectivity, and social construction: reflections from the study of gay and lesbian communities", Sociological Research Online, Vol. 13 No. 1, pp. 1-7.

Ingraham, C. (2006), "Thinking straight, acting bent: heteronormativity and homosexuality", in Davis, K., Evans, M. and Lorber, J. (Eds), Handbook of Gender and Women Studies, Chapter 17, Sage, London, pp. 307-480.

Jenkins, R. (2008/2014), Social Identity, Routledge, Abingdon.

Kandola, R. and Fullerton, J. (1998), Diversity in Action, CIPD, London.

Liff, S. and Wajcman, J. (1996), "'Sameness' and 'difference' revisited: which way forward for equal opportunity initiatives?”, Journal of Management Studies, Vol. 33 No. 1, pp. 79-94.

Local Government Act (1988), available at: www.legislation.gov.uk/ukpga/1988/9/contents

McDowell, L. and Court, G. (1994), "Performing work: bodily representations in merchant banks", Environment and Planning D: Society and Space, Vol. 12 No. 6, pp. 727-750. 
Mclvor, A. (2014), Working Lives. Work in Britain Since 1945, Palgrave, Basingstoke.

Martin, J. and Dean, L. (1993), "Developing a community sample of gay men for an epidemiological study of AIDS", in Renzetti, C. and Lee, R. (Eds), Researching Sensitive Topics, Sage, London, pp. 7898.

Miller, S., Forset, K. and Jurik, N. (2003), "Diversity in blue: lesbian and gay police officers in a masculine occupation", Men and Masculinities, Vol. 5 No. 4, pp. 355-385.

Platzer, H. and James, T. (1997), "Methodological issues conducting sensitive research on lesbian and gay men's experience of nursing care", Journal of Advanced Nursing, Vol. 25 No. 3, pp. 626-633.

Rumens, N. (2008), "Working at intimacy: gay men's workplace friendships", Gender, Work and Organization, Vol. 15 No. 1, pp. 9-30.

Rumens, N. and Broomfield, J. (2012), "Gay men in the police: identity disclosure and management issues", Human Resource Management Journal, Vol. 22 No. 3, pp. 283-298.

Rumens, N. and Kerfoot, D. (2009), "Gay men at work: (Re) constructing the Self as professional", Human Relations, Vol. 62 No. 5, pp. 763-786.

Rumens, N. and Tyler, M. (2016), "Queer theory", in Mir, R., Willmott, H. and Greenwood, M. (Eds), The Routledge Companion to Philosophy in Organization Studies, Routledge, New York, NY, pp. 225236.

Shallenberger, D. (1994), "Professional and openly gay. A narrative study of the experience", Journal of Management Inquiry, Vol. 3 No. 2, pp. 119-142.

Shilling, C. (1993), The Body and Social Theory, Sage, London.

Ward, J. (2008), Sexualities, Work and Organizations, Routledge.

Webb, J. (1997), "The politics if equal opportunity", Gender, Work and Organization, Vol. 4 No. 3, pp. 159-169.

Whitehead, S. (2002), Men and Masculinities: Key Themes and New Directions, Polity, Cambridge. Young, I. (1990), Justice and the Politics of Difference, Princeton University Press, Princeton, NJ.

\section{Further reading}

Benozzo, A., Pizzorno, M.C., Bell, H. and Koro-Ljungberg, M. (2015), “Coming out, but into what? Problematizing discursive variations of revealing the gay self in the workplace", Gender, Work \& Organization, Vol. 22 No. 3, pp. 292-306.

Haynes, K. (2012), "Body beautiful? Gender, identity and the body in professional services firms", Gender, Work and Organization, Vol. 19 No. 15, pp. 489-507.

Parker, M. (2002), "Queering management and organization", Gender, Work and Organization, Vol. 9 No. 2, pp. 146-166. 
Pullen, A., Thanem, T., Tyler, M. and Wallenberg, L. (2016), "Sexual politics, organizational practices: interrogating queer theory, work and organization", Gender, Work and Organization, Vol. 23 No. 1, pp. 1-6.

Sedgewick, E. (1990), Epistemology of the Closet, University of California Press, Berkeley, CA.

Seidman, S. (1996), Queer Theory/Sociology, Blackwell, Oxford.

Warner, M. (1993), Fear of a Queer Planet: Queer Politics and Social Theory, University of Minnesota Press, Minneapolis, MN. 


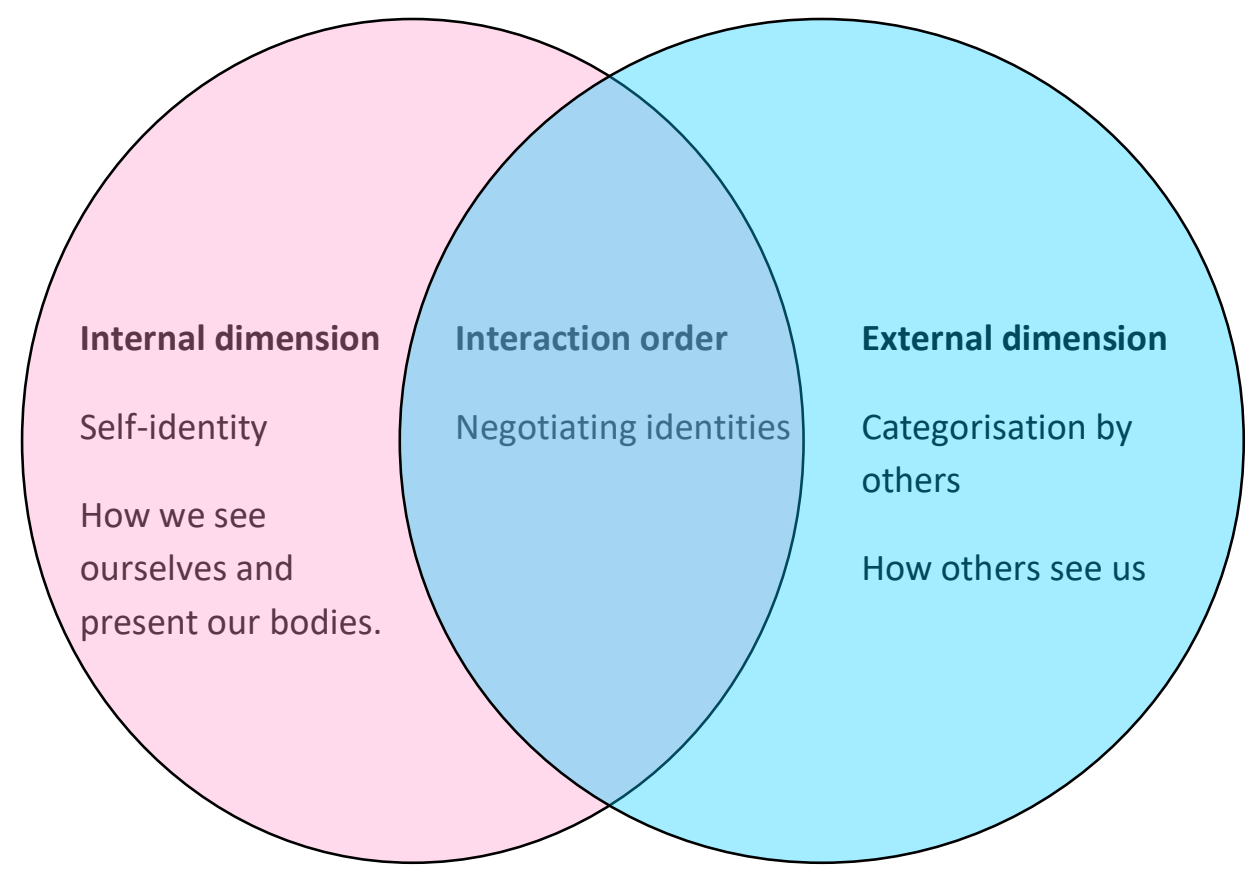

Figure 1: The intersection of internal and external dimensions of identity. 
Table 1: Study participant profiles.

\begin{tabular}{|c|c|c|c|}
\hline Name & Age & Occupation & $\begin{array}{l}\text { Organisational } \\
\text { environment }\end{array}$ \\
\hline Pablo & 31 & $\begin{array}{l}\text { Primary school } \\
\text { teacher }\end{array}$ & \\
\hline Ivan & 43 & Shop floor manager & $\begin{array}{l}80 \text { employees, male } \\
\text { dominated, only gay } \\
\text { employee. }\end{array}$ \\
\hline Stan & 35 & $\begin{array}{l}\text { Deputy head of } \\
\text { primary school }\end{array}$ & $\begin{array}{l}\text { Mixed gender, } \\
\text { 'Accepting' of gay } \\
\text { men. }\end{array}$ \\
\hline Reg* & 63 & Surveyor & $\begin{array}{l}\text { Male dominated } \\
\text { environment in } \\
\text { building industry. }\end{array}$ \\
\hline Godfrey & 47 & $\begin{array}{l}\text { Environmental health } \\
\text { officer }\end{array}$ & $\begin{array}{l}\text { Small department, } \\
\text { mainly middle aged } \\
\text { men. Only gay } \\
\text { employee. }\end{array}$ \\
\hline Dean & 42 & Police Constable & $\begin{array}{l}\text { Extensive diversity } \\
\text { training courses, } \\
\text { aware of } 4 \text { gay } \\
\text { employees. }\end{array}$ \\
\hline Nigel & 29 & $\begin{array}{l}\text { Secondary school } \\
\text { teacher }\end{array}$ & $\begin{array}{l}\text { Mixed gender with } 60 \\
\text { staff and gay deputy } \\
\text { head. }\end{array}$ \\
\hline Pat* & 52 & Lawyer & $\begin{array}{l}\text { Male dominated } \\
\text { directorship, macho } \\
\text { environment. }\end{array}$ \\
\hline
\end{tabular}

* Participants who had not disclosed their gay identity in the workplace. 